A Summary of Three Regional Assessment Studies of Solar Electric Generation Opportunities in the Southwest, Southeast, and Northeast United States
R. L. Watts
H. Harty

February 1981

Prepared for the U.S. Department of Energy under Contract DE-AC06-76RLO 1830

Pacific Northwest Laboratory Operated for the U.S. Department of Energy by Battelle Memorial Institute 
NOTICE

This report was prepared as an account of work sponsored by the United States Government. Neither the United States nor the Department of Energy, nor any of their employees, nor any of their contractors, subcontractors, or their employees, makes any warranty, express or implied, or assumes any legal liability or responsibility for the accuracy, completeness or usefulness of any information, apparatus, product or process disclosed, or represents that its use would not infringe privately owned rights.

The views, opinions and conclusions contained in this report are those of the contractor and do not necessarily represent those of the United States Government or the United States Department of Energy.

\author{
PACIFIC NORTHWEST LABORATORY \\ operated by \\ BATTELLE \\ for the \\ UNITED STATES DEPARTMENT OF ENERCY \\ Under Contract DE-AC06-76RLO 1830
}

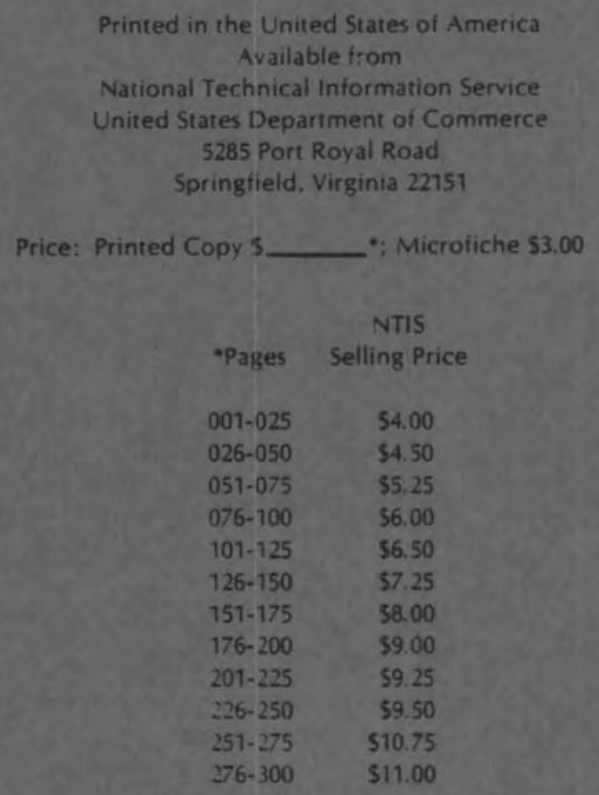




\section{A SUMMARY OF THREE REGIONAL ASSESSMENT STUDIES OF SOLAR ELECTRIC GENERATION OPPORTUNITIES IN THE SOUTHWEST, SOUTHEAST, AND NORTHEAST UNITED STATES}
R. L. Watts
H. Harty

February 1981

Prepared for the U.S. Department of Energy under Contract DE-AC06-76RLO 1830

Pacific Northwest Laboratory Richland, Washington 99352 
.

.

. 
SUMMARY

Market opportunities $(a)$ for solar generation of electricity for utility and for residential/commercial/industrial applications in the Northeast, Southeast, and Southwest regions of the United States were evaluated in three studies (JBF 1979, Stone \& Webster 1979a, 1979b) and are summarized in this report. The evaluations were based on both economic analyses and user perception of what they would require to select or approve the use of solar electric generation for themselves or for the ir employers. Over 30 utilities and several industrial and commercial firms and homeowners were involved; input from homeowners was derived primarily in eight user workshops.

The studies projected that solar electric technologies could account for several percent of the forecast generation in year 2000 in the Southeast and Southwest regions, and up to 10 to 20 percent in the Northeast region. No single solar electric technology or application (for utility or industrial/ commercial/residential use) arrived earlier at economic breakeven than other technologies in the Southeast region, but wind generation for both utility and industrial applications predominated in the Northeast region. The Southwest region, in which only utility applications were considered, showed wind energy and retrofit hybrid (a solar adjunct to an existing fossil-fueled plant) to be the most likely early applications.

Before this market penetration occurs, several important factors must take place.

- Through the year 2000 energy prices from conventional fuels must rise several percent per year faster than the rate of inflation.

- Department of Energy (DOE) cost and performance goals for solar electric technologies must be met on schedule.

- Enough solar electric technologies must be demonstrated successfully to overcome potential users' concerns.

(a) The term "market opportunities" is defined as those situations in which technically mature solar electric equipment will be preferred economically by prospective users compared to competing options for meeting their electrical (generating) needs. 
- Incentives(a) must be available to reduce risk and to overcome barriers that potential users perceive. To achieve a 5\% market penetration of the Southwest region, financial incentive requirements were estimated at $\$ 11$ billion through the year 2000 .

The three Regional Assessment Studies (RAS) were performed during a period of relatively stable fuel costs and in which petroleum fuel escalations averaged several percent per year above general inflation. The reports were completed just prior to the spectacular price increases of 1979-80 in which petroleum fuel costs doubled.

While such large increases (above general inflation) are unlikely to be an every-year occurrence, the actual increases experienced were significantly larger than those assumed in these studies. Coupled with the large fuel cost increases were significant government legislative and administrative actions that encouraged the development of renewable energy resources. Therefore, because the analyses made in the RAS do not reflect all the recent actions and economic factors, they may be conservative.

(a) In this report the term "incentives" is defined as any governmental action that is taken to encourage generation of solar electric energy. 


\section{CONTENTS}

SUMMARY

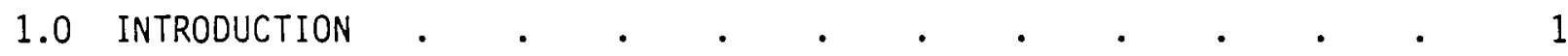

2.0 REGIONAL ELECTRICAL ENERGY NEEDS

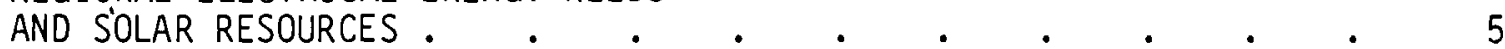

3.0 FUTURE COSTS AND AVAILABILITY OF SOLAR ELECTRIC

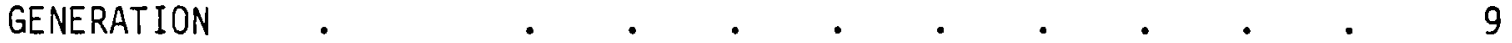

4.0 WHERE AND WHEN SOLAR ELECTRIC GENERATION IS A GOOD INVESTMENT $\quad$ • 13

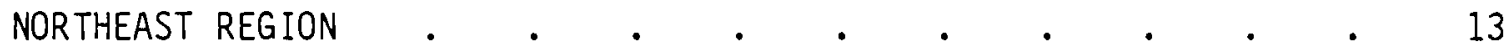

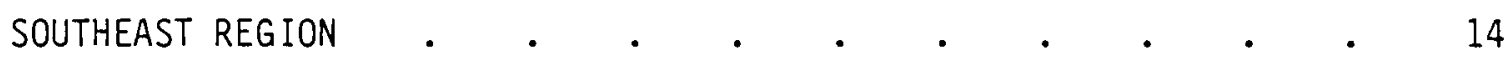

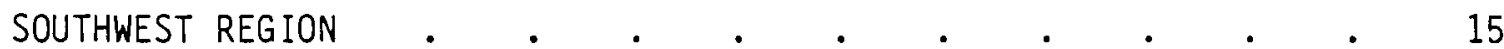

MAJOR FACTORS AFFECTING THE CALCULATED VALUE

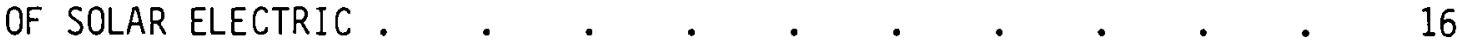

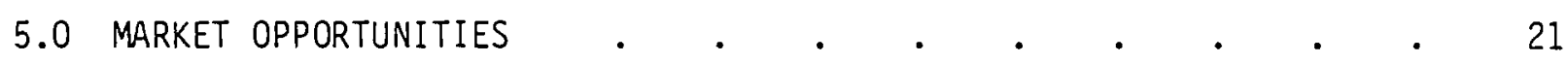

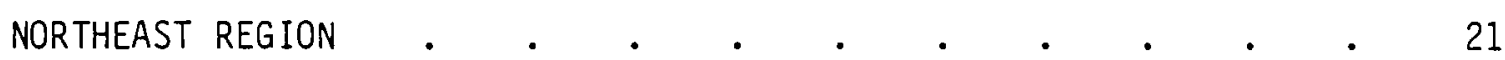

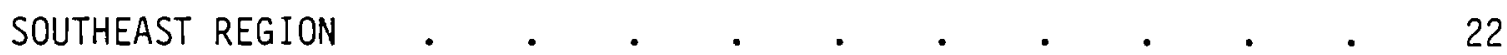

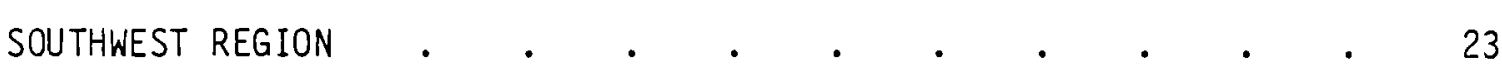

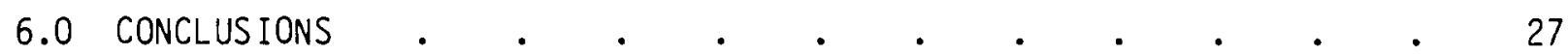

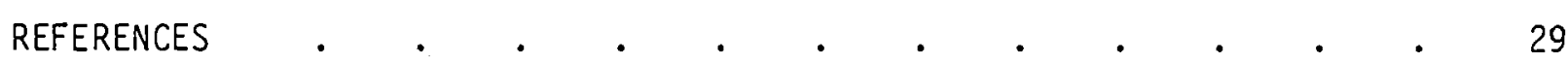


.

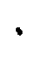




\section{A SUMMARY OF THREE REGIONAL ASSESSMENT STUDIES \\ OF SOLAR ELECTRIC GENERATION OPPORTUNITIES \\ IN THE SOUTHWEST, SOUTHEAST, AND \\ NORTHEAST UNITED STATES}

\subsection{INTRODUCTION}

This report summarizes and synthesizes the results of Regional Assessment Studies (RAS) completed for the Northeast, Southeast, and Southwest regions of the U.S. Using methods and assumptions selected by the study teams, each study estimated its region's market opportunities for solar electric generation to the year 2000 .

The Northeast, Southeast, and Southwest studies were completed in early 1979. The Northeast study was performed by JBF Scientific Corporation, while Stone \& Webster Engineering Corporation performed the Southeast and Southwest study. (a) Each study involved electric utilities (referred to as central users or the central station case and listed in Table 1) in the respective regions. The Northeast and Southeast studies also involved residential owners and commercial/industrial firms (referred to as dispersed users or the dispersed user case) and included representatives of government, industry, financial institutions, taxation groups, consumer groups, environmentalists, and manufacturers. Dispersed users were primarily involved through workshops, listed in Table 2.

As shown in Table 3, the solar electric technologies considered included biomass, hybrid retrofit, ocean thermal energy conversion (OTEC), photovoltaic, solar thermal, and wind.

Utility systems were modeled using codes employed by utilities, or ones similar to them, in which solar electric options were substituted for more

(a) The remaining regions are being studied in contracts awarded by the Solar Energy Research Institute and include the following: North Central Region - Gilbert/Commonwealth Associates; South Central Region - Science Applications, Inc; and Northwest Region - JBF Scientific Corporation. 
TABLE 1. Electric Utilities Involved in Central Case Studies

Northeast

Boston Edison Company
Central Maine Power
New England Gas and
Electric Association
New England Power
Pool
New England Power
Service Company
Niagara Mohawk Power
Corporation
Northeast Utilities
Public Service
Electric and Gas
Company

Southeast

Baltimore Gas and

Electric Company

Duke Power Company

Florida Power

Corporation

Florida Power and

Light Company.

Jacksonville Electric

Authority

Puerto Rico Water

Resources Authority

Savannah Electric and

and Power Company

Southern Company

Services

Tampa Electric Company

Tennessee Valley

Authority

Southwest

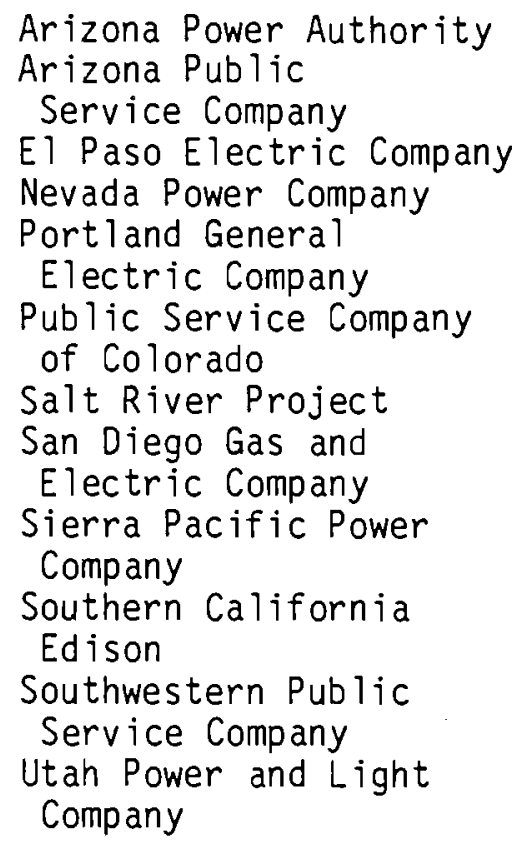

TABLE 2. Dispersed Case User Workshops

Northeast

Four Community Task Force Workshops Burlington, Vermont

New England Center for Energy

Policy Workshop,

Cambridge, Massachusetts
Southeast

Residential User Workshop, Or lando, Florida

Residential User Workshop, Alexandria, Virginia

Nonresidential User Workshop, Atlanta, Georgia

conventional generating options. The changes in system generating costs were calculated for a range of assumptions previously reviewed with participating utilities. Drawing upon utility practices, the amount of solar electric generation that could be incorporated in utility systems versus time was then estimated. (a)

(a) The estimates included judgment considerations on several factors such as availability of incentives to defray cost penalties, engineering readiness of the solar electric option, and the need for demonstration plants. 
TABLE 3. Solar Electric Technologies Evaluated in RAS

\begin{tabular}{|c|c|c|c|c|c|}
\hline \multirow[b]{2}{*}{ Techno logy } & \multicolumn{2}{|c|}{ Northeast } & \multicolumn{2}{|c|}{ Southeast } & \multirow{2}{*}{$\begin{array}{l}\text { Southwes } \\
\text { Central }\end{array}$} \\
\hline & Central & Dispersed & Central & Dispersed & \\
\hline Biomass & - & & - & & \\
\hline Hybrid Retrofit & & & & & - \\
\hline OTEC & - & & - & & \\
\hline Photovolta ic & - & - & - & - & - \\
\hline Solar Thermal & $\bullet$ & $\bullet$ & $\bullet$ & $\bullet$ & $\bullet$ \\
\hline Wind & - & - & - & - & - \\
\hline
\end{tabular}

For the dispersed case, typical solar electric options, including cost data, were described to prospective users. Users were asked to decide when and under what conditions solar electric options would be of interest to them. Based on their responses, estimates were made of a) likely installed capacity for the dispersed user case, and $b$ ) the amount of subsidy required.

The remainder of this sumary report describes the regions' electrical needs and solar resources, the availability and cost of solar generating options, locations and times when commercial solar electric systems will be available, regional market opportunities, and proposed strategies derived from synthesis of the regional studies. Note that the Northeast and Southeast studies used a 1978 data base, while the Southwest used a 1977 data base. 


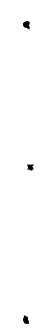




\subsection{REGIONAL ELECTRICAL ENERGY NEEDS AND SOLAR RESOURCES}

None of the regions studied have firm plans for solar electric generation, and present plans through the year 2000 depend on traditional resources. The ten-year National Electric Reliability Council forecasts no use of solar electric generation and estimates to the year 2000 are uncertain about its role. Fuel resource projections for electrical generation are listed in Table 4. Regional forecasts indicate that annual electrical demand is expected to grow 3.1\% per year in the Northeast, $2.6 \%$ in the Southeast, and $5 \%$ in the Southwest. Population increases projected are $1 / 2 \%$ per year for the Northeast region and about 1-1/2\% per year for the Southeast and Southwest regions.

All three regions look to nuclear for substantial generation of electrical power. The Southeast and Southwest regions plan to use more coal to reduce their dependence (percentage-wise) on gas and oil. However, both the Northeast and Southwest regions plan to increase their present consumption of gas and $0 i 1$. The Northeast, without significant energy resources, is most heavily dependent on energy imports.

TABLE 4. Fuel Resources Projected for Electric Generation

\begin{tabular}{|c|c|c|c|c|c|c|}
\hline \multirow[b]{2}{*}{ Central Generation } & \multicolumn{2}{|c|}{ Northeast } & \multicolumn{2}{|c|}{ Southeast } & \multicolumn{2}{|c|}{ Southwest } \\
\hline & $\begin{array}{l}\text { Present } \\
(1978) \\
\end{array}$ & $2000(a)$ & $\begin{array}{l}\text { Present } \\
\text { (1978) }\end{array}$ & 2000 (b) & $\begin{array}{l}\text { Present } \\
(1977)\end{array}$ & $2000(c)$ \\
\hline Gas and $0 i 1$ & $51 \%$ & $39 \%$ & $26 \%$ & $14 \%$ & $67 \%$ & $35 \%$ \\
\hline Coal & 11 & 11 & 50 & 42 & 20 & 32 \\
\hline Nuc lear & 24 & 39 & 13 & 40 & 3 & 27 \\
\hline $\begin{array}{l}\text { Hydro, Geothermal } \\
\text { and Energy Storage }\end{array}$ & 14 & 11 & 10 & 4 & 1 & 6 \\
\hline
\end{tabular}

(a) Based on JBF Scientific Corporation projections.

(b) Based on Electric Power Research Institute projections.

(c) Based on utility projections. 
In the Northeast, wind is a very significant resource with many excellent sites potentially available with 500 watts $/ \mathrm{m}^{2}$ yearly average at 50 meter heights. Biomass in the form of wood products could supply up to about $4 \%$ of the region's fuel for electrical generation to the year 2000. The insolation resource is modest, averaging 3 to $4 \mathrm{kWh} / \mathrm{m}^{2} /$ day and no OTEC resource is available.

In the Southeast, growing conditions are excellent for producing biomass. An ultimate biomass potential is estimated at 70 to $140 \mathrm{GWe}$, although that amount would require up to $40 \%$ of the 1 and area. Using $1 \%$ of the 1 and area, solar thermal could provide $250 \mathrm{GWe}$. The insolation resources are somewhat better than the Northeast, averaging 4 to $5 \mathrm{kWh} / \mathrm{m}^{2} /$ day. However, because the sunshine tends to be scattered by haze or clouds, concentrating devices are less effective in the Southeast than in other regions. Ocean temperature differences exceed $20^{\circ} \mathrm{C}$ on a yearly average in large areas of the Gulf of Mexico and offshore Puerto Rico, making OTEC a real possibility for the Southeast, with an estimated 200 to $600 \mathrm{GWe}$. The wind resources are not we 11 characterized, but appear to be modest, perhaps as high as 300 to 400 watts $/ \mathrm{m}^{2}$ in selected areas and located away from load centers.

In the Southwest, the insolation resource is excellent. Numerous sites average $6 \mathrm{kWh} / \mathrm{m}^{2} /$ day and could increase to $7.5 \mathrm{kWh} / \mathrm{m}^{2} /$ day with clear air and concentrating devices tracking the sun. Some wind sites are believed to be as good as wind sites in other regions, but these are not well characterized and some appear to be remote from load centers. The region does not have sufficient water to support adequate land-based biomass production, and the ocean temperature difference is not enough to seriously consider OTEC.

The regional attitude that appears to characterize the potential users involved in the RAS studies can be sumarized as follows:

- The Northeast appears to be more aware that it has a serious electrical energy problem and the temperament of the region is to act to solve it. Increasing electricity costs, coupled with a continued dependency on $0 i 1$ and gas, are motivating factors. 
- The Southeast does not appear to perceive the same crisis in electrical energy that the Northeast does. The closer proximity to indigenous fuel resources, the lower electricity costs, and a warmer climate may be contributing factors to the difference.

- The Southwest appears highly aware that the solar potential can contribute to their energy requirements, but the region is not of a common mind concerning its energy supply. The region appears to be highly attracted to the solar option and is supporting it in legislation and through utility initiatives.

In sumary, the three regions studied project significant growth in electrical generation to the year 2000; all have excellent solar resources for one or more technologies, yet none of the utilities are including significant quantities of solar electric generation in their projections. 
<smiles>C1CCC1</smiles>

- 


\subsection{FUTURE COSTS AND AVAILABILITY OF SOLAR ELECTRIC GENERATION}

The three RAS provided an excellent opportunity to understand how prospective users view availability, cost, and institutional barriers of solar electric technology.

Utilities perceive the availability of solar electric generating options as beyond their usual planning horizon. Until generating options are proven to be ready for commercialization, they will not be considered in utilities' expansion plans. Twenty-five years ago a similar situation existed for nuclear power--the technicians and vendors considered it commercially viable at least 5 to 10 years before the users (utilities) did. Figure 1 (from the Southeast study) shows the dates solar electric options might be available for commercial operation, assuming that utilities will build plants soon after a full-sized demonstration plant begins operation. When utilities perceive that risk is great, several years of operation or additional demonstration plants may be required. It is apparent that a significant time elapses (typically 4 to 6 years) between successful operation of demonstration plants and operation of first generation utility plants.

This time elapse involves a) operation of a full-sized demonstration plant for at least one year to give utilities confidence to order similar units, and b) data collection, licensing, construction, and startup, which are estimated to consume four to six years or more if site selection has not been previously completed. Few additional orders are placed until a utility's first-of-a-kind electric plant comes on line and operational experience is gained. Because of these factors, not much utility solar electric capacity can be expected by the year 2000. Further, without successful operating experience from full-sized demonstration plants, utilities are not likely to include significant solar electric in their planning forecasts.

Dispersed users have little or no concept of future availability of solar electric options for their applications. Figure 2 (also from the Southeast study) represents the earliest probable technical maturity dates for onsite solar electric facilities. 


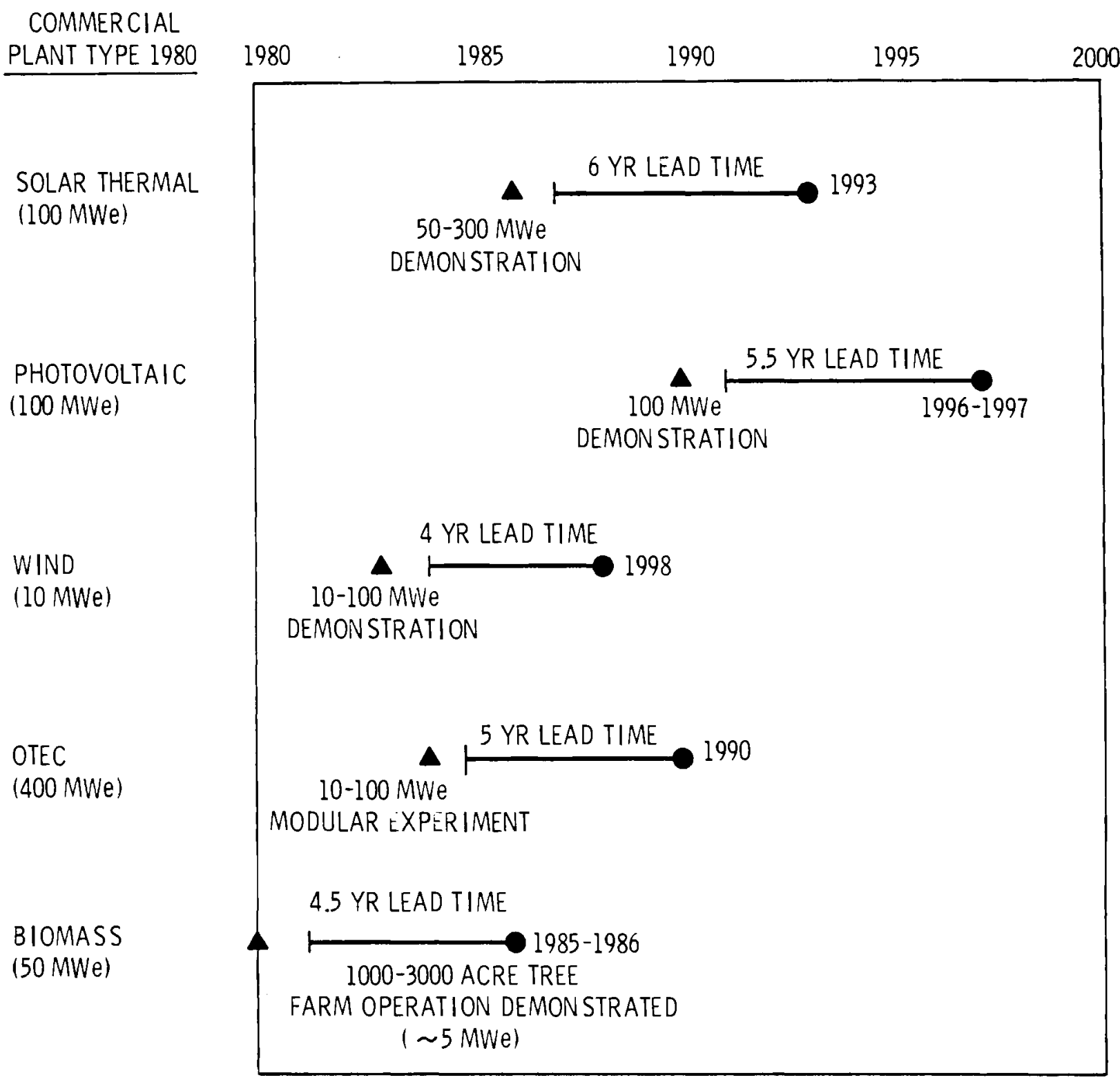

- DENOTES FIRST OPERATION OF A FULL-SCALE DEMONSTRATION PLANT BASED ON DOE PROGRAM PLANS

- DENOTES EARLIEST OPERATION OF FIRST GENERATION OF UTILITY ORDERS LEAD TIME INCLUDES 3 YEARS FOR DATA COLLECTION AND LICENSING, BUT EXCLUDES SITE SELECTION EFFORT

FIGURE 1. Utilities' Views of Earliest Probable Technical Maturity of Representative Solar Electric Central Stations from Southeast Study 


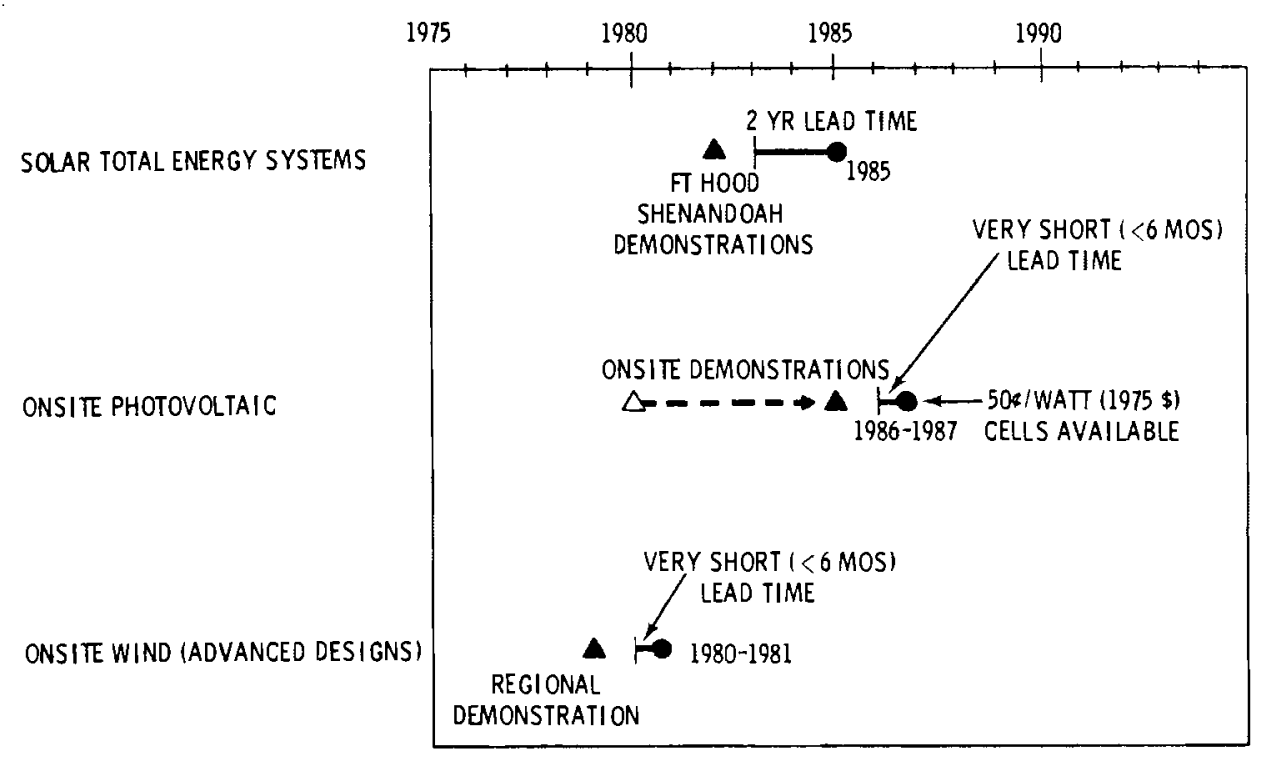

- DENOtes OpERATION OF MULTIPLE DEMONSTRATIONS

- deNOTES EARLIER OPERATION OF FIRST GENERATION OF USER-PURCHASED UNITS

FIGURE 2. Earliest Likely Technical Maturity of Representative Onsite Solar Electric Facilities

After onsite (i.e., dispersed) solar electric generating facilities are demonstrated, shorter lead times (compared to utility applications) are required to install additional units. Considerable additional time may be required, however, to develop an adequate infrastructure to support a dispersed market.

The technical maturity dates presented in Figures 1 and 2 assume that DOE cost goals for solar electric are met as presently forecast. Table 5 shows the estimated solar electric plant costs when balance-of-plant costs for the entire system are added to the DOE cost goals. The differences among regions reflect many regional factors, including different solar resource and balanceof-plant cost assumptions.

Some utility representatives expressed skepticism about achieving these estimated costs. Dispersed users expressed no uniform understanding of whether estimated costs for systems of interest to them were too high or too low. 
TABLE 5. Solar Electric Total Plant Cost Estimates (Circa 2000 Expressed in 1977 or 1978 Dollars) (\$/kWe Installed Capacity)

\begin{tabular}{|c|c|c|c|}
\hline Technology & \multicolumn{3}{|c|}{ Region } \\
\hline Central Station & $\frac{\text { Northeast }}{(1978)}$ & $\frac{\text { Southeast }}{(1978)}$ & $\frac{\text { Southwest }}{(1977)}$ \\
\hline Wind & $\$ 500-700$ & $\$ 800-1100$ & $\$ 920-1230$ \\
\hline $\begin{array}{l}\text { Solar Thermal } \\
\text { (Central Receiver Type) }\end{array}$ & $1500-1800$ & $2200-2700$ & $1470-2200$ \\
\hline Photovoltaic & $900-1100$ & $1300-1700$ & $1300-1700$ \\
\hline Retrofit Hybrid & -- & -- & $1040-1740$ \\
\hline OTEC & -- & $1500-2600$ & -- \\
\hline Biomass & 1300 & $1100-1300$ & - \\
\hline Dispersed Applications & & & \\
\hline Photovoltaics & $\$ 600-1000$ & $\$ 500-1000$ & Not Studiec \\
\hline Wind & $1000-1250$ & $700-1000$ & Not Studied \\
\hline Solar Thermal & & $6800-9100$ & Not Studied \\
\hline
\end{tabular}




\subsection{WHEN AND WHERE SOLAR ELECTRIC GENERATION IS A GOOD INVESTMENT}

Using the costs and time schedules from the preceding section, the various solar electric options were used in utility planning models to calculate their value to utilities. For dispersed users, the payback periods were calculated. Value and payback are not the only criteria users may apply to solar electric generation, but users are unlikely to buy if system costs cannot be recovered over a reasonable period. Results of these calculations are presented in the following sections.

\section{NORTHEAST REGION}

Biomass and wind are the best options for Northeast utilities. Assuming fuel escalation of $3 \%$ per year above inflation, biomass will have a positive net value to utilities as early as 1980, while a positive value for good wind sites will occur as early as 1991, as shown in Figure 3.

For the dispersed user, wind machines for large-scale industrialcommercial installations installed during or after 1980 achieve breakeven (a) almost immediately on a life cycle basis; (b) for medium-scale commercial-industrial break-even is achieved in 1982; and for residences break-even occurs in 1987. Photovoltaics achieve break-even if installed in 1987 for residences and medium-scale commercial-industrial applications, and break-even occurs in the late 1990s for large-scale commercial-industrial applications. Other solar electric options considered do not achieve life-cycle break-even for utilities or dispersed users before the year 2000.

If fuel escalates at the same rate as general inflation, then the dates for payback cited above will be delayed for five to ten years. An important factor that surfaced in dispersed user workshops was that most dispersed users will not purchase when the payback period is equal to the equipment lifetime, but rather, require a 3 - to 5-year break-even period.

(a) Break-even is the point at which the savings in purchased electricity are equal to the investment (including capital and operating costs) for the facility.

(b) Life cycle is estimated at 15 to 30 years. 


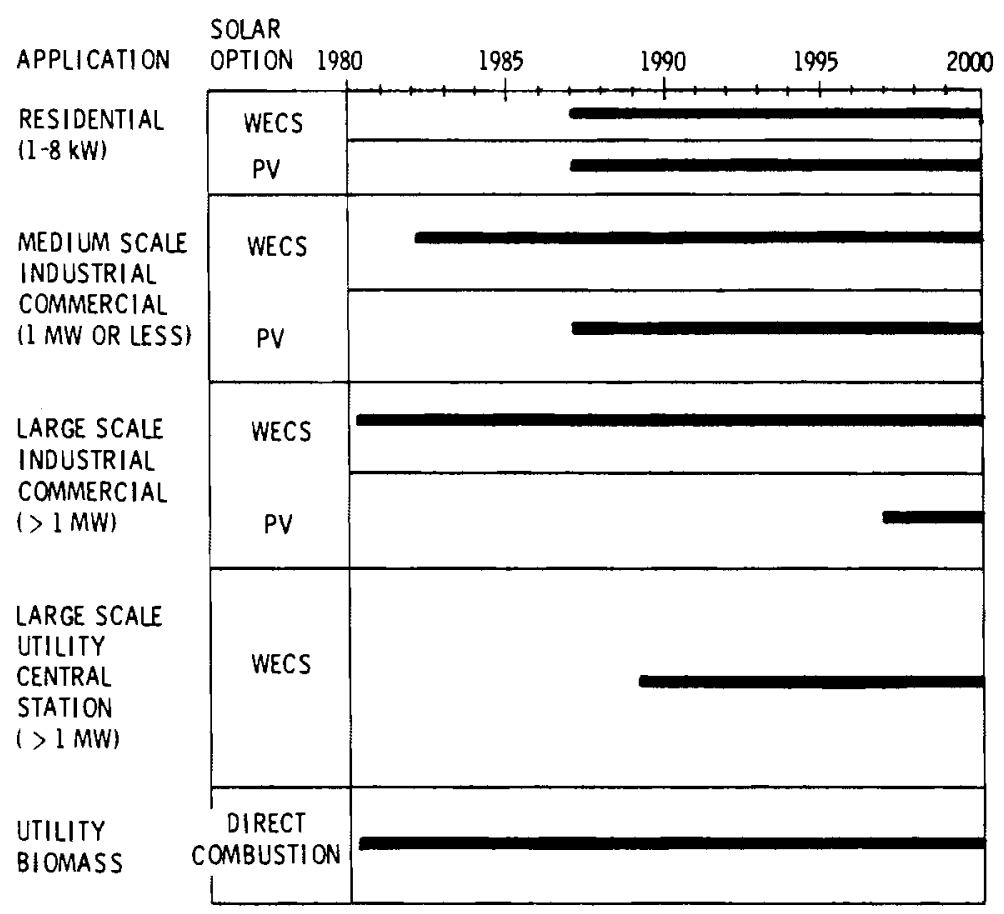

ASSUMPTIONS:

- 1978 ENERGY ACT EXTENDED

- electric rate escalates 3\% PER year above 6\% PER year INFLATION; UTILITY FUEL PRICES ESCALATE AT 3\% PER YEAR ABOVE 6\% PER YEAR INFLATION

- UTILITY SELLBACK OF EXCESS ENERGY AT LIIKWH MINIMUM

- doe hardware cost goals are met

- commercial hardware is available

- bIOMASS SUPPLy PROBLEMS ARE SOLVEO

FIGURE 3. Period in which Solar Electric Payback is Achieved Over the Equipment Lifetime

SOUTHEAST REGION

For utilities, no central station solar electric options showed a net positive value before the year 2000 if fuel escalates at the same rate as inflation (Table 6). If fuel escalates $4 \%$ per year above general inflation, then OTEC and wind show positive values in the $1990 \mathrm{~s}$. 
TABLE 6. Cost and Value of Solar Electric Options to Utilities in the Southeast (In $1978 \$ / k W e$ for Year 2000)

\begin{tabular}{|c|c|c|c|}
\hline Plant Type & $\begin{array}{c}\text { Estimated } \\
\text { Range of Mature } \\
\text { Plant Costs (a) } \\
\end{array}$ & $\begin{array}{l}\text { Estimated Amoun } \\
\text { "Afford" to Pay } \\
\text { At } 6 \% \text { Fue } 1 \\
\text { Inflation (b) }\end{array}$ & $\begin{array}{l}\text { Utilities Can } \\
\text { for the Plants } \\
\text { At } 10 \% \text { Fuel } \\
\text { Inflation (c) }\end{array}$ \\
\hline \multicolumn{4}{|l|}{ Central Stations } \\
\hline Solar Thermal Electric & $2,000-2,500$ & $200-400$ & $500-800$ \\
\hline Photovoltaic & $1,300-1,700$ & $300-400$ & $500-800$ \\
\hline Wind & $800-1,000$ & $300-400(c)$ & $800-900(c)$ \\
\hline Biomass (Wooc) & $1,100-1,300$ & $<400^{(d)}$ & $<700$ \\
\hline OTEC & $1,500-2,600$ & $800-1,300$ & $2,000-3,100$ \\
\hline
\end{tabular}

(a) Assumes DOE cost goals are met; based on modeling two utility systems for the year 2000 .

(b) Value is determined by modeling the fuel and capacity savings resulting from the operation of the solar unit for utility systems selected. Fuel inflation rates include general inflation of $6 \%$ annually based on 1978 assumptions.

(c) Based on results of the Southwest project for wind sites with $26 \%$ capacity factor.

(d) Based on simple comparison of $50 \mathrm{MW}$ wood-fueled plant with $600 \mathrm{MW}$ coalfired plant.

For the dispersed user case residential photovoltaics can achieve payback (over equipment lifetime) in the late 1990s if fuel escalates at the same rate as inflation (Table 7). Wind can achieve payback in the early 1990s with a net $4 \%$ escalation in fuel costs.

\section{SOUTHWEST REGION}

No solar electric option achieved break-even in the Southwest based on fuel escalations assumed by the utilities for their systems (Table 8 - Note footnote $\mathrm{C}$ ).

The value of the solar electric options depends partly on assumed fuel costs. The primary fuels for electric power generation in the Southwest are gas and 011 , which are used to generate $67 \%$ of the electric power; coal provides $20 \%$, nuclear $3 \%$, hydro and diesel less than $1 \%$. 
TABLE 7. Break-Even Dates for Onsite (Dispersed) Solar Electric Options in the Southeast

Onsite Power Generating Facilities

Solar Total Energy Systems (Industrial) After 2000 After 2000

Photovoltaic (Residential)

Late 1990s Early 1990s

Wind

Estimated Break-Even Dates ( $a, b)$

\begin{tabular}{ll}
$6 \%$ Energy & $10 \%$ Energy \\
Inflation $(c)$ & Inflation $(c)$ \\
\hline
\end{tabular}

After $2000 \quad$ Early 1990s

(a) Assumes DOE cost goals are met; favorable rate structures are applied to user-owned systems.

(b) The break-even date is the point at which the savings in purchased electricity are equal to the investment required for the facility.

(c) Fuel inflation rates include general inflation of $6 \%$ annually based on 1978 assumptions.

Fuel costs for the Southwest Region are presented in Table 9. One Southwest utility, Salt River Project, achieved economic break-even by the year 2000 for solar thermal with an 8 to $10 \%$ fuel escalation rate (again including $6 \%$ general inflation) primarily because solar replaced expensive oil fuel and the utility has a low fixed-charge interest rate.

\section{MAJOR FACTORS AFFECTING THE CALCULATED VALUE OF SOLAR ELECTRIC}

A very clear conclusion from the RAS is that most solar technologies are not economical prior to the year 2000 if fue 1 costs and electricity prices are assumed to escalate at the same rate as general inflation. Even a substantially more rapid escalation of fuel costs ( 2 to $4 \%$ above general inflation) is still not sufficient for a many technologies to penetrate the market. Therefore, many incentives (including demonstration and financial-type incentives) appear to be required (barring increased long-term fuel escalation) before any significant installation of solar electric generation will occur before the year 2000 in each of the three regions studied. 
TABLE 8. Cost and Value of Solar Electric Options to Utilities in the Southwest in 1985 (in $1977 \$ / \mathrm{kWe}$ )

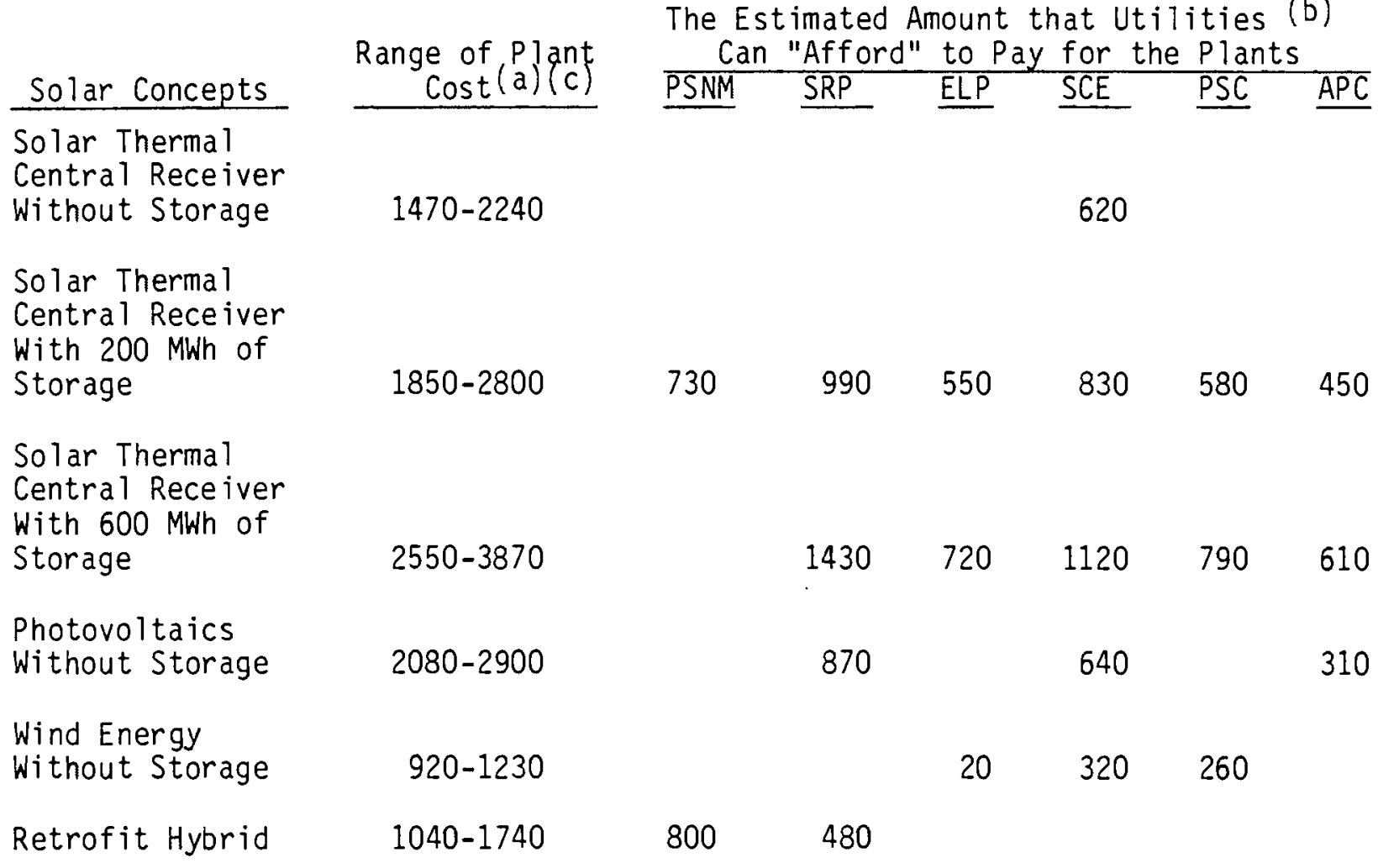

(a) Plant costs include interest during construction and owner's costs, but not contingencies.

(b) PSNM--Public Service of New Mexico; SRP--Salt River Project; ERLP--El Paso Electric Company; SCE--Southern Cal ifornia Edison Company; PSC--Public Service Company of Colorado; APC--Arizona Public Service Company.

(c) Fuel escalation rates varied from 4 to $8 \%$ per year for coal; 5 to $8 \%$ for 011 ; and 4 to $8 \%$ for nuclear, based on 1977 assumptions.

The RAS suggested that initial opportunities for solar electric generation cannot be identified on a national or even regional basis. Initial opportunities must be sought utility by utility (or maybe within a single utility's service area) or on an individual, industrial, commercial, or residential basis. This situation exists for several reasons: 
TABLE 9. Fuel Cost (mills/kWh) in Year 2000

for Utilities in Southwest Study

\begin{tabular}{|c|c|c|c|}
\hline \multirow[b]{2}{*}{ Utility } & \multicolumn{3}{|c|}{ Fue 1 Type } \\
\hline & Coal & 011 & Nuclear \\
\hline PSNM & 46.0 & -- & 20.0 \\
\hline SRP & 36.3 & 184.5 & 13.0 \\
\hline ELP & 45.9 & 85.9 & 12.5 \\
\hline SCE & 33.7 & 127.9 & 25.5 \\
\hline PSC & 52.1 & 167.7 & 10.4 \\
\hline APS & 26.4 & 83.2 & 15.9 \\
\hline
\end{tabular}

1. Prices for fuel vary widely among and even within regions. In the year 2000, Southwest coal costs are estimated to vary from 26 to 52 $\mathrm{mills} / \mathrm{kWh}$, depending on the long-term contracts the utility has in place.

2. Electric costs reflect the current and anticipated mix of generating equipment. Some utilities expect to be, or will be, heavily dependent on oil far into the future. Fuel cost increases for these utilities can be expected to exceed general inflation.

3. Some solar resources are markedly different within the regions. Even within utility service areas, wind and biomass may vary considerably. Further, solar resources that are greatest at or near the peak electricity demand periods are of greatest value.

4. The value of solar electric generation depends on whether the electricity is generated by a utility or by a user who has his own facility. Solar electric central stations displace plants with more expensive fuels (and provide some generating capacity), while onsite systems replace retain electricity sensitive to rate structures.

5. The regulations, tax laws, and accounting rules differ from utility to utility and from dispersed user to dispersed user. Solar electric appears to have a greater value for public-owned (municipal) utilities (with lower fixed-charge rates) than for investor-owned utilities. 
Early market opportunities will need to be sought through careful consideration of individual situations. 


\subsection{MARKET OPPORTUNITIES}

The RAS unanimously concluded that no significant market opportunities will exist for solar technologies before the year 2000 unless:

- fuel and electricity prices rise at least several percent faster per year than the rate of inflation through the year 2000

- DOE cost and performance goals for appropriate solar electric options are met on schedule

- many demonstrations of each solar electric option are sufficiently successful to overcome user concerns

- incentives are available initially to reduce risk and overcome barriers that users foresee.

These factors were the present composite views of electric utilities involved in the studies. Dispersed users could not state their position as clearly, but the same factors generally apply in their case also.

Because most participating utilities do not believe that the probability of these factors occurring is great, negligible amounts of solar electric presently exist in the region's electrical generation plans for the year 2000 . However, if the factors do occur, then the RAS projections of solar market opportunities are as presented in Table 10.

The most promising solar electric options for each region are discussed in the following sections.

\section{NORTHEAST REGION}

Market opportunities in the Northeast emerge primarily because of an excellent wind resource and high electricity costs. Some biomass resource also exists. For the dispersed market, the major users are likely to be industrial firms (pulp and paper, chemicals, refineries, and primary metals). This market potential was estimated to be about 400 large (2.5 MWe) wind machines by 1990 and double that number by the year 2000. The market opportunity for users accepting life cycle break-even costs occurs in early to mid-1980s. 
TABLE 10. Estimated Regional Solar Electric Market Opportunity (Year 2000)

Solar \% of Regions' Total Installed Electric Capacity

Northeast

Southeast

Southwest (a)

$$
10-20
$$

$0.5-3.0$

3.5
Forecast of Total Installed Solar Electric Capacity GWe

$19-35$

$4-14$

8

(a) Southwest case includes central station case only extrapolated to all utilities in the southwest.

An estimated 190,000 homes could be equipped with photovoltaics by the year 2000, and about 28,000 homes could have wind machines, accounting for about 900 Mwe. Apartment houses could add one-third more generation.

The utility market opportunity, based on economic analysis only, was estimated to be as high as 14,000 large (2.5 MWe) wind machines with a generating capacity of 35,000 MWe by the year 2000 . Most utility planners feel that this figure is too high and cannot be achieved economically. In any case, the market entry opportunity is expected to occur about 1990.

The utility market opportunity for biomass (direct combustion) is estimated to be about 2000 MWe by the year 2000. In some situations biomass is economically viable today. Its long-range use depends partly on the competition for the wood resource.

The entire dispersed solar electric market could account for $2.3 \%$ of the Northeast's electrical requirement; the utility market could be as large as $20 \%$, but siting and other problems will probably reduce this figure.

\section{SOUTHEAST REGION}

Based on the RAS, the market opportunities before the year 2000 for solar electricity in the Southeast are almost nonexistent for utilities (less than 1000 MWe for each of OTEC and biomass). Residential and other dispersed photovoltaics, a market that is very difficult to quantify, is estimated at between 2000 and 12,000 MWe by the year 2000. If fuel costs escalate at $4 \%$ 
per year above general inflation, the higher figure will be more likely to be achieved, and the utility market may be expanded somewhat.

On the surface, Southeast market opportunities appear to be smaller than the Northeast's, despite a superior solar resource (apart from wind). However, by assuming similar fuel cost escalation rates, the Southeast market is likely to be somewhat larger, maybe 15,000 MWe, or approximately that which may be expected in the Northeast. The low cost of wind machines, the superior wind resource and higher electricity costs create the advantage for solar use in the Northeast. The Southeast has superior solar resources (again, apart from wind), but lower electricity costs, less dependence on high cost fuels, and superior fuel supplies. If the selected target year had been 2010 or 2020, the Southeast market might have been larger by comparison due to further maturity of the solar electric technologies most appropriate to the region.

A higher fuel escalation rate relative to inflation could change the opportunity for solar electric options in the Southeast. Utility planners tended to think in terms of fuel escalation rates close to those for general inflation. Also, if cost, schedule, and performance goals are achieved by DOE for OTEC, higher penetrations are likely; however, utility participants were skeptical that these goals would be achieved. Utilities are attracted to OTEC (and wood-fueled plants) because they have the potential to operate up to 80 to $90 \%$ of the time, whereas wind plants may operate on ly 10 to $30 \%$, and photovoltaic plants 15 to $16 \%$ of the time. Thus, in terms of energy, $1 \mathrm{MW}$ of wood or OTEC plant capacity may be worth 4 to $6 \mathrm{MW}$ of wind or photovoltaic plant capacity due to greater availability.

The Southeast has an enormous solar resource, but limited short-term (year 2000) market opportunities. Achieving higher penetration rates may be possible by applying cost and risk sharing incentives and institutional arrangements. The Southeast's overall market penetration picture to the year 2000 is presented in Table 11.

\section{SOUTHWEST REGION}

Although the Southwest has the best insolation resource in the U.S., it has a continuing heavy dependence on $0 i l$ and gas for electric generation. 
TABLE 11. Estimated Solar Electric Generating Capacity and Resource Limits in Southeast to Year 2000

\begin{tabular}{|c|c|}
\hline Technology & $\begin{array}{l}\text { Maximum Credible } \\
\text { Penetration }\end{array}$ \\
\hline $\begin{array}{l}\text { Wood-Fue led Central } \\
\text { Station Generation }\end{array}$ & $500-1000 \mathrm{MW}$ \\
\hline $\begin{array}{l}\text { Ocean Thermal Central } \\
\text { Station Energy Conversion }\end{array}$ & $100-900 \mathrm{MW}$ \\
\hline $\begin{array}{l}\text { Multi-Unit Wind Central } \\
\text { Stations }\end{array}$ & $<500 \mathrm{MW}$ \\
\hline $\begin{array}{l}\text { Solar Thermal Central } \\
\text { Stations }\end{array}$ & Negligible \\
\hline $\begin{array}{l}\text { Photovoltaic Central } \\
\text { Stations }\end{array}$ & Negligible \\
\hline $\begin{array}{l}\text { Onsite Photovoltaic } \\
\text { Residential } \\
\text { Nonresidential }\end{array}$ & $\begin{array}{l}1000-7000 \mathrm{MW} \\
1000-5000 \mathrm{MW}\end{array}$ \\
\hline $\begin{array}{l}\text { Onsite Wind } \\
\text { Residential } \\
\text { Nonresidential }\end{array}$ & $\begin{array}{l}<50 \mathrm{MW} \\
\text { Negligible }\end{array}$ \\
\hline Solar Total Energy Systems & Negligible \\
\hline
\end{tabular}

Like the Southeast, the projected cost of solar electric plants, long-term (low-cost) fuel contracts, and other factors work against solar electric. No significant market potential was identified for solar electric through year 2000. However, assuming Federal incentives were available to compensate for differences between investment cost and value to the utilities, the installed capacity to the year 2000 (for the utilities participating) was optimistically estimated by the utilities to be as high as 8000 MWe. Federal incentives estimated at $\$ 11$ billion would be required to achieve this degree of regional penetration by the year 2000 . These incentives would make up the difference between the cost of solar electric plants and their value to the utilities. 
In general, increasing the fuel escalation rate to $10 \%$ (again including general inflation) through the year 2020 can double the value of solar electric generation to investor-owned utilities, displacing coal and oil-fired capacity. To sumarize, the estimated market opportunities to the year 2000 for solar electric in three regions are presented in Table 12.

TABLE 12. Estimated Market Opportunities for Solar Electric to Year 2000

\begin{tabular}{|c|c|c|}
\hline Region & Utility Case & Dispersed Case \\
\hline Northeast & 16,000 to 32,000 MWe & 3000 MWe \\
\hline Southeast & 2000 MWe & 2,000 to $12,000 \mathrm{MWe}$ \\
\hline Southwest & $8000 \mathrm{MWe}(\mathrm{a})$ & not estimated \\
\hline
\end{tabular}

(a) Extrapolated to all utilities in the Southwest region. 


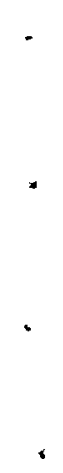




\subsection{CONCLUSIONS}

In addition to the conclusions that resulted from the analyses for the RAS, several strong, consistent messages were given by prospective users:

- Both central and dispersed users have positive attitudes toward the various solar electric technologies and wish to see them as available options, but the lack of convincing demonstrations and specific knowledge of the solar resource hinders them from formulating plans to implement solar electric systems in their organizations or locations even if the projected economics were attractive.

- Users are wary of the obstacles and pitfalls of installing solar electric technologies and want assurance, preferably in the form of demonstrations, that they won't suffer financially or otherwise be embarrassed. Most dispersed users require electric utility backup service.

- Dispersed users are sensitive to whether or not an installed solar electric technology will alienate or have a positive effect on neighbors or customers.

- Typically, users feel that they should not have to assume all the economic risk of early units, i.e., risks of early obsolescence or decreased resale value of homes.

- Users want a solar electric infrastructure in place or at least being developed to provide installation and maintenance services.

- Dispersed users especialiy need help in defining whether or not an adequate solar resource is available to them.

Based on prior analyses and these and other user inputs, several actions were proposed to accelerate solar electric use in the three regions studied:

- All regions need to have their solar resources better defined. Presently, a major deterrent to solar electric use is that sites with adequately defined solar resources cannot be selected. 
- All regions need significant demonstrations of various solar electric technologies. Examples for the Northeast would be demonstration of a wind-energy farm (a cluster of several hundred large wind machines at a single site), several hundred large wind machines in dispersed locations in electricity-saver roles, and photovoltaics on several hundred homes. For the Southeast wood-fueled and wind central station applications, dispersed wood, wind, and photovoltaic, and an OTEC pilot plant are identified for demonstration. For the Southwest, several large ( 100 MWe) demonstration plants (retrofit. hybrid, solar thermal central receiver, and photovoltaics) appear warranted. Demonstration of full-size solar electric generating technologies will be critical to the establishment of investor and user confidence.

- A range of Federal and state incentives, costing as high as several billion dollars per region, is required for these and other demonstration units. A broad range of conventional incentives is appropriate for utilities. For residential users, loans that reduce the risk and facilitate resale may be appropriate. 


\section{REFERENCES}

JBF Scientific Corporation. 1979. Northeast Regional Assessment Study for Solar Electric Options in the Period 1980-2000. JBF Co., Wilmington, Massachusetts.

Stone and Webster Engineering Corporation, et al. 1979a. Southeast Regional Assessment Study. An Assessment of the Opportunities for Solar Electric Power Generation in the Southeastern United States. Stone and Webster, Boston, Massachusetts.

Stone and Webster Engineering Corporation, et al. 1979b. Southwest Project Resource/Institutional Requirements Analysis. Stone and Webster, Boston, Massachusetts. 
.

-

. 
PNL-3030

UC -13

DISTRIBUTION

No. of

Copies

A. A. Churm

DOE Chicago Operations Office 9800 South Cass Avenue

Argonne, IL 50439

Edwin Hudspeth

Staff Director

Alabama Development Office

State Capito 1

Montgomery, AL 36130

Charles A. Powe 11

Baltimore Gas \& Electric Company

PO Box 1475

Baltimore, MD 21203

J. R. Tieman

Baltimore Gas \& Electric Company

PO Box 1475

Baltimore, MD 21203

Nicholas Biederman

Management Consultant

$1666 \mathrm{~W} 104 \mathrm{Place}$

Chicago, IL 60643

Ash is Gupta

Coprporate Engineering

Coca Cola Company

PO Box 1734

Atlanta, GA 30301

David L. Press, Executive Director

Delaware Governor's Energy Office

Townsend Bldg.

Dover, DE 19901

Edward C. Fiss

Duke Power Company

422 South Church St.

Charlotte, NC 28242
No. of

Copies

27 DOE Technical Information Center

Larry Sitney

The Aerospace Corporation

D-5 B Idg., Room 2002E

PO Box 92957

Los Angeles, CA 90009

Bill Hibbs

The American Wind Energy Association

$1717 \mathrm{~K}$ Street NW

Suite 1111

Washington, DC 20036

Michael Santor $i$

Department of Planning \& Energy Policy

20 Grand Street

Hartford, CT 06155

Lee Barrett

Solar Market Integration Division

Solar Power Applications

DOE Conservation \& Solar Applications

600 E Street NW

Washington, DC 20585

Joseph L. Barrow, Director

Commercialization

DOE Conservation \& Solar

App 1 ications

1000 Independence Avenue SW

Washington, DC 20585

Bever ly Berger

Biomass Energy Systems Division

Solar Applications for Industry

DOE Conservation \& Solar

Applications

600 E Street NW

Washington, DC 20585 
No. of

Copies

Gerald Braun

Solar Thermal Energy Systems

Division

Solar Applications for Industry

DOE Conservation \& Solar

Applications

600 E Street NW

Washington, DC 20585

John B. Cadogan

Office of Strategy Analysis

and Integration

DOE Conservation \& Solar Applications

1000 Independence Avenue SW

Washington, DC 20585

Lynn Collins

Consumer Motivation Finance Branch

Buildings \& Community Systems

DOE Conservation \& Solar

Applications

1000 Independence Avenue SW

Washington, DC 20585

William L. Corcoran

International Programs

DOE Conservation \& Solar

Applications

1000 Independence Avenue SW

Washington, DC 20585

Lou is $V$. Divone

Wind Energy Division

Solar Power Applications

DOE Conservation \& Solar

Applications

$600 \mathrm{E}$ Street NW

Washington, DC 20585

Robert Jordan

Market Development Division

Solar Applications for Buildings

DOE Conservation \& Solar

Applications

1000 Independence Avenue SW

Washington, DC 20585
No. of

Copies

\author{
Andrew Krantz \\ Photovoltaics Division \\ Solar Applications for Buildings \\ DOE Conservation \& Solar \\ Applications \\ 1000 Independence Avenue SW \\ Washington, DC 20585 \\ Norman Lutkefedder \\ Market Testing \& Applications Branch \\ Solar Applications for Buildings \\ DOE Conservation \& Solar \\ Applications \\ 1000 Independence Avenue SW \\ Washington, DC 20585 \\ Paul Maycock \\ Photovoltaics Division \\ Solar Applications for Buildings \\ DOE Conservation \& Solar \\ Applications \\ 1000 Independence Avenue SW \\ Washington, DC 20585 \\ Bennett Miller \\ Deputy Assistant Secretary \\ Solar Energy \\ DOE Conservation \& Solar \\ Applications \\ 1000 Independence Avenue SW \\ Washington, DC 20585 \\ John Millhone, Director \\ Buildings is Community Systems \\ DOE Conservation \& Solar \\ Applications \\ 1000 Independence Avenue SW \\ Washington, DC 20585 \\ John E. Mock \\ Science \& International Programs \\ Solar Energy \\ DOE Conservation \& Solar \\ Applications \\ 1000 Independence Avenue SW \\ Washington, DC 20585
}


No. of

Copies

Frederick H. Morse, Director Solar Applications for Buildings DOE Conservation \& Solar Applications 1000 Independence Avenue SW Washington, DC 20585

J. Michael Power, Director Policy Planning \& Evaluation DOE Conservation \& Solar Applications 1000 Independence Avenue SW Washington, DC 20585

Walter Preysnar Program Development Branch Solar Applications for Buildings DOE Conservation \& Solar Applications 1000 Independence Avenue SW Washington, DC 20585

James Quinn

Planning \& Technology Transfer Office Solar Energy

DOE Conservation \& Solar Applications 1000 Independence Avenue SW Washington, DC 20585

John Bigger, Project Manager Solar Thermal Conversion Electric Power Research Institute PO Box 10412

Palo Alto, CA 94303

John E. Cummings, Director Renewable Resource Systems Dept. Electric Power Research Institute PO Box 10412

Palo Alto, CA 94303

Edgar A. DeMeo, Manager Solar Power Systems Program Electric Power Research Institute PO Box 10412

Palo Alto, CA 94303
No. of

Copies

Walt Esselman, Director

Strategic Planning Department

Electric Power Research Institute PO Box 10412

Palo Alto, CA 94303

Frank R. Goodman, Jr.

Project Manager, Technical Asses sments

Solar Power Systems

Electric Power Research Institute PO Box 10412

Palo Alto, CA 94303

Sam Schurr, Deputy Director

Electric Power Research Institute PO Box 10412

Palo Alto, CA 94303

Dante Ionata, Director

Energy Capability and Management

Governor's Energy Office

State House

Providence, RI 02903

Robert Hirsh, Director Energy Management Office

Edgar A. Brown Bldg. 1205 Pendleton St. Columbia, SC 29201

Roy Shive Energy Management Office Edgar A. Brown Bldg. 1205 Pendleton St. Columbia, SC 29201

Frank Castellon, Director Energy Office of Puerto Rico Box 41089

Minallas Station

Santurce, PR 00940

Henry Lee, Director Energy Policy office McCormick Bldg., 14th Floor 1 Ashburton Place Boston, MA 02108 
Hal Scott

Florida Audubon Society

PO Drawer 7

Maitland, FL 32751

Charles Hinson

Florida Energy Office

301 Bryant Bldg.

Tallahassee, FL 32304

Helge Swanson

Florida Governor's Energy Office Capitol

Tallahasse, FL 32301

Roger N. Roark

Flor ida Power Corporation

PO Box 14042

St. Petersburg, FL 33733

Paul R. Sutherland

Florida Power \& Light Company

PO Box 013100

Miami, FL 33101

W. R. McCluney

Florida Solar Energy Center

300 State Road 401

Cape Canaveral, FL 32920

Peter Walley, Administrator

Fuel \& Energy Management Commission

1307 Woolfolk Bldg.

Jackson, MS 39205

Sheldon Jeter

Department of Mechanical

Engineering

Georgia Institute of Technology

Atlanta, GA 30332

Wayne Parker, Director

Georgia Office of Energy Resources

270 Washington Street SW

Atlanta, GA 30334
Edward Ney/Walter Hensley Georgia Power Company PO Box 4545

Atlanta, GA 30302

Norman Van der Noot

Executive Director

Governor's Council on Energy

3 Capitol Street

Concord, NH 03301

R. J. Cole

Human Affairs Research Centers

4000 NE 41 Street

Seattle, WA 98105

Dave Cowen

Institute of Gas Technology

3424 South State St.

IIT Center

Chicago, IL 60616

John Q. Carter, Jr.

Jacksonville Electric Authority

Box 53015

Jacksonville, FL 32201

Robert W. Neal

JBF Scientific Corporation

2 Jewel Drive

Wilmington, MA 01887

Morris M. Bryan, Jr. Jefferson Mills Inc.

PO Box 526

Jefferson, GA 30549

Donald E. Melsten, Director Maryland Energy Policy Office Suite 1302

301 W Preston St.

Baltimore, MD 21201

J. R. Smith

New England Power Pool

174 Brush $\mathrm{Hill}$ Avenue

West Springfield, MA 01089 
No. of Copies

J. Joseph Grandmaison

Federal Co-Chairman

New England Regional Commission

53 State Street

Suite 400

Boston, MA 02109

Denn is O'Malley, Director

New Jersey State Energy Office 101 Commerce Street

Newark, NJ 07102

R. A. Merrill, Jr. Operating Manager

New York Power Pool

3890 Carmen Road

Schenectady, NY 12303

Ms. Wendy Wild

New York State Energy Office

Empire State Plaza

Agency Building No. 2

Albany, NY 12223

Richard M. Wood

Manager, R\&D Projects

Environment \& Resource Utilization

Niagara Mohawk Power Corp.

300 Erie Blvd. West, Bldg C-3

Syracuse, NY 13202

Dr. Lance Heiko

Northeast Solar Energy Center

70 Memorial Drive

Cambridge, MA 02142

Robert Goodrich

Northeast Utilities Service Company

PO Box 270

Hartford, CT 06101

Gary Linton, Acting Director

Office of Energy Resources

State House

Augusta, ME 04333
No. of

Copies

Walter Pate

411 East Estes

Midland, TX 79701

W. S. Kleinback, Manager

Pennsylvania-New Jersey-Maryland Interconnection 955 Jefferson Avenue

Valley Forge Corporate Center

Norristown, PA 19401

Rafael Llavina, Jr.

Puerto Rico Water Resources Authority

GPO Box 4267

San Juan, PR 00936

Winfield C. Smith

Savannah Electric and Power Company 600 Bay Street $E$

Savannah, GA 31402

Berry Butler

General Research Division

Solar Energy Research Institute

1617 Cole Boulevard

Golden, CO 80401

Donald Feucht

Photovoltaics Division

Solar Energy Research Institute 1617 Cole Boulevard

Golden, CO 80401

Henry Kelly

Analysis \& Applications

Directorate

Solar Energy Research Institute

1617 Cole Boulevard

Golden, CO 80401

Herbert Landau

Information Systems Division

Solar Energy Research Institute

1617 Cole Boulevard

Golden, CO 80401 
Clayton Smith

Chemical \& Biological Division

Solar Energy Research Institute

1617 Cole Boulevard

Golden, CO 80401

Kenell Touryan

Research \& Development Directorate

Solar Energy Research Institute

1617 Cole Boulevard

Golden, CO 80401

Jon Veigel

Planning Applications \& Impacts Division

Solar Energy Research Institute

1617 Cole Boulevard

Golden, CO 80401

Robert Witholder

Economic Analysis

Solar Energy Research Institute

1617 Cole Boulevard

Golden, CO 80401

Neil Woodley

Utilities \& Industry Division

Solar Energy Research Institute

1617 Cole Boulevard

Golden, CO 80401

Ben C. Ruche

South Carolina Energy Research Inst.

Suite 670

First National Bank Bldg.

Main at Washington

Columbia, SC 29201

Richard H. Chastain, Manager

Technology Assessment Programs

Research Department

Southern Company Services, Inc. PO Box 2625

Birmingham, AL 35202
Michael Jack/Dan Smith Southern Solar Energy Center

Planning Project

Exchange Place Suite 1250

2300 Peachford Road

Atlanta, GA 30338

Brendan J. Whittaker, Director

State Energy Office

Personnel Building

Montpelier, VT 05602

3 Donald H. Guild, Project Manager

Stone \& Webster Engineering Corp.

PO Box 2325

Boston, MA 02107

Duncan Moodie

Stone \& Webster Engineering Corp.

1875 I Street NW

Suite 550

Washington, DC 20006

William J. Johnson

Tampa Electric Company

PO Box 111

Tampa, FL 33601

Eugene Edmonds

Tennessee Valley Authority

250 Capitol Hill Bldg.

Nashville, TN 37219

Graham R. Siege 1

Power Research Staff

Tennessee Valley Authority

1360 Commerce Union Bank Bldg.

Chattanooga, TN 37401

John Yolton

International Union

United Auto Workers

8000 E Jefferson

Detroit, MI 48214 
No. of

Copies

\section{ONSITE}

George Jones

Virginia State Energy Office

823 E Main St.

Richmond, VA 23219

Lee $C$. White

115615 Street NW

Suite 302

Washington, DC 20005

DOE Richland Operations Office

H. E. Ransom

29 Pacific Northwest Laboratory

F. W. Albaugh

C. H. Bloomster

J. W. Currie

D. E. Deonigi

K. Drumheller

T. J. Foley

R. K. Had lock

H. Harty

A. J. Haverfield

W. W. Laity

V. E. Lee

W. V. Loscutoff

A. M. Sutey

R. L. Watts (5)

L. L. Wende 11

E. V. Werry

L. D. Willi ams

T. L. Willke

Technical Information (5)

Publishing Coordination (2) RK 
נ

-

. 